hatchory-reared $1+$ smolts. There are some grounds for believing that thyroid treatment could improve survival of smolts during the period of osmotic stress when they first enter tidal water, ${ }^{3,4}$. This may apply more particularly to hatchery-reared smolts which necessarily have been subjected to some handling.

In this small experimont there was an incrcase of 80 per cent in the production of $1+$ smolts for an increase of not more than 25 per cent in the feeding costs for the first year. However, had these 400 fish not become $1+$ smolts, the cost of keeping them for a further full year would have been considerably more than the cost of thyroid material used in transforming them into $1+$ smolts. The comparison in other districts may be even more favourable than in County Mayo, where the cost of thyroid material is high, relative to that of low-grade liver. Experimental work on lowered dosage-rates is planned for the coming season.

Farran Laboratory, Newport,

\section{J. Piggins} Co. Mayo, Eire.

${ }^{1}$ Barrington, E. J. W., Barron, N., and Piggins, D. J., Gen. and Comp. Endocrinol., 1, 170 (1961).

${ }^{3}$ Piggins, D. J., Thesis, Univ. Nottingham (1958).

3 Smith, D. C. W., Mem. Soc. Endocrinol, 5, 83 (1955).

- Fontaine. M., and Baraduc., M. M., Bull. Franc. Pisc., 176, 89 (1955),

\section{Culture of Spinellus}

Mounds of tho genus Spinellus of the Mucorales are generally regarded as being obligate parasites of agaries, particularly those belonging to the genus Mycena. Recontly, Ellis and Hessoltine' reported that they had grown a species of Spinellus in pure culture; they noted the difficulty of making the spores germinate, and demonstratod the necessity for a relatively low temperature (below $20^{\circ} \mathrm{C}$.) for growth.

Last autumn, a culture of Spinellus $\mathrm{sp}$. was obtained from a parasitized fruit-body of Mycena galopus. The isolation was made by placing spores on a modium, later referred to as the 'basal medium', containing glucose, salts and yeast extract. A rapidly growing mycelium developed, producing numerous sporangia resombling those on the parasitized agaric. The mould has since been maintained in culture, using mycelium for inoculation as it proved to be very difficult to make the spores germinate. Various natural media have been tried, as well as tho basal medium, and 5 per cent corn-meal agar also gave good growth, although others seemed less suitablo.

This isolate, like that obtained by Ellis and Hesseltine, was extremely sensitive to temperature. No growth was obtained with cultures kept above $23^{\circ} \mathrm{C}$. and the optimum seemod to be about $20^{\circ} \mathrm{C}$. At this and lower temperatures numorous sporangia were produced, with sporangiophores up to about $1.5 \mathrm{~cm}$. tall. Cultures incubatod at $22^{\circ}-23^{\circ} \mathrm{C}$. producod fewer sporangia, containing fewer sporos, and with much shorter sporangiophores.

Tho spores from cultures grown at a low temperature $\left(13^{\circ} \mathrm{C}\right.$. was used in theso experiments) were elongatod in form, with a ratio of longth/breadth of about $3: 1$. Culturos grown at $22 \cdot 5^{\circ} \mathrm{C}$. produced relatively shorter and broader spores with a length/ breadth ratio of about $2: 1$. The actual size of tho spores varied somewhat according to the modium but the relative shapes were the same on different media and seemed to depend on the temperature at which the culture had been grown.
Various attempts have been made to dotermine the conditions necessary for spore germination and some relevant observations have boen made. Spores germinate readily in contact with the fruit-body of a suitable agaric but only rarely on culture media. Some of the broador spores produced by cultures grown at $22 \cdot 5^{\circ} \mathrm{C}$. on corn-meal agar or basal medium germinated in water or nutrient solutions or on agar media, whereas spores produced by cultures grown at $13^{\circ} \mathrm{C}$. did not germinate under these conditions.

Mycelium which devoloped from gorminatod spores produced, when grown at $13^{\circ} \mathrm{C}$., the types of sporangia and spores characteristic for that temperature. There is thus no permanent change inducod by growth at $22 \cdot 5^{\circ} \mathrm{C}$., but the spores produced differ in their shape and ability to germinate from those produced at lower temperatures. This presumably explains the successful initial isolation of Spinellus, as the spores used came from sporangia which had developed in the laboratory, at a temperature which was probably suitable for the production of the broader type of spore and the isolate could have rosulted from the germination of one or more of these. Previous unsuccessful attempts had beon made to isolate from sporangia devoloped in the field, and the spores, presumably of the narrower type, would not germinate on culturo media.

Apart from bringing them into contact with a suit. able agaric fruit-body, one other way has been found of obtaining somo germination of sporos at lower temperatures. This was to place them in association with various unidentified bacteria, which were first acquired as contaminants. The substance which stimulates germination appeared to diffuse through "Cellophano' but has not so far been demonstrated in a Seitz filtrate of liquid cultures of the bactoria.

A more detailed account of these investigations will be published later and it is also hoped to study further the factors necessary for spore germination in Spinellus and other aspocts of its rolationship with its hosts.

Dopartment of Botany,

Pauline Watson

Durham Colleges in the

University of Durham.

${ }^{1}$ EIllis, J. J., and Hesseltine, C, W., Nuture, 193, 699 (1962).

\section{ENTOMOLOGY}

\section{Identification of Iso-Amyl Acetate as an Active Component in the Sting Pheromone of the Honey Bee}

THE sting of the honoy bee (Apis mellifera L.) carries volatile substances which incito beos to aggression. This was first domonstrated by Hubor ${ }^{1}$, who elicited attacks by the guard bees when he placed freshly excisod stings or the odour of stings nenr the hive entrance. Freo ${ }^{2}$ found that cotton balls contrining stings were more froquently stung than control balls.

When not in action, the sting is retracted entiroly within the sting chamber of the bee's abdomen. However, in the event of attack, tho sting is quickly protruded and thrust into the enemy. The worker bee is usually unable to withdraw her barbed sting from the skin of vertebrates. Thus, the sting with its motor apparatus and glands is torn from the beo along anatomically predetermined breaking lines. 